\title{
O SEGUNDO REITORADO DE D. FRANCISCO DE LEMOS NA UNIVERSIDADE DE COIMBRA: UMA AÇÃO CONJUNTA?
}

\author{
Carlos Fernando Teixeira Alves ${ }^{1}$
}

\section{RESUMO}

D. Francisco de Lemos, original do Rio de Janeiro, onde nasceu em 1735, foi Reitor da Universidade de Coimbra durante 31 anos (dividido em dois momentos, 1770-1779 e 1799-1821) e, entre outros cargos, foi também Bispo de Coimbra durante pouco mais de duas décadas. Mas neste artigo pretendo apenas analisar o seu segundo reitorado (17991821), a sua atividade política, educacional e de gestão universitária. Parte significativa deste seu segundo reitorado contou também com um contributo essencial, José Monteiro da Rocha, vice-reitor e Lente de matemática. A relação profissional e pessoal entre ambos começou antes de 1772, mas é neste reitorado e no seu contexto atribulado - devido principalmente as invasões francesas -, que podemos ver uma ação conjunta na direção da Universidade de Coimbra. Com o intuito de analisar esta colaboração foi possível selecionar 135 cartas trocadas entre eles durante 1799 e 1816, e que cobrem parte do reitorado. Como método de análise, e tendo em conta o elevado número de missivas, foi necessário incluir as várias referências encontradas nas cartas em assuntos e, por sua vez, em grupos mais abrangentes que permitissem identificar padrões de análise.

Palavras-chave: D. Francisco de Lemos; Reitor; Universidade de Coimbra; José Monteiro da Rocha.

\section{THESECONDRECTORSHIPOF D. FRANCISCODE LEMOSINTHE UNIVERSITYOF COIMBRA: ANJOINT ACTION?}

\begin{abstract}
D. Francisco de Lemos born in the Rio de Janeiro in 1975and was Rector of the University of Coimbra for 31 years (divided in two moments, 1770-1779 and 1799-1821), and Bishop of Coimbra for more than two decades, among other positions. In this article,I aim to analyze the second retorship (1799-1821), this politicaland educational activity, and this university administration in this period. A significant part of this rectorship have an important contribute from José Monteiro da Rocha, vice rector and math teacher. The relationship, personal and professional, of both start after 1772, but was in this rectorship and in this complex context -mainly because the French Invasions -, that we can see a conjunct action in the administrative of the University of Coimbra. For analyses this collaboration it's possible to find 135 letters exchanged between both during 1799 to 1816, that cover part of the rectorship. As a method of analysis, and considering the large number of missives, it was necessary to include the various references found in the letters in subjects and, in turn, in larger groups that allowed to identify patterns of analysis.
\end{abstract}

Key-words: D. Francisco de Lemos; Rector; University of Coimbra; José Monteiro da Rocha. 


\section{Introdução}

A reitoria da Universidade de Coimbra era um lugar privilegiado dentro da própria instituição. Dai o Reitor ser, como é referido nos estatutos, a cabeça da universidade. Mas, tendo em conta a importância da universidade no contexto nacional e internacional, alcançar a reitoria e chefiar assim a instituição, pode ser encarado comouma posição de poder e influência. Ao Reitor cabia então a administração da vida universitária. Neste centravam-se as decisões essenciais ao bom funcionamento da instituição. A ele competia decidir sobre praticamente todas as matérias, poder que lhe foi substancialmente aumentado ao longo da época moderna. Escolhido pelo monarca, a este cabia também a ligação da universidade com outras instituições e poderes. Era o Reitor que representava a universidade junto do monarca. Daqui, podemos concluir que estamos a falar de um cargo importante, e neste caso em especifico, foi onde D. Francisco de Lemos (que para além de reitor também foi reformador), muito provavelmente mais se evidenciou. E nesta sua segunda nomeação para reitor(1799-1821), a primeira conclusão que devemos retirar é que foi antecipadamente pensada e preparada. Com a criação da Junta da Diretória Geral dos Estudos (e com o evidente processo de centralização que já vinha a acontecer pelo menos desde 1791), Francisco de Lemos começa a apresentar-se de novo como uma peça essencial - sendo decisivo quanto à escolha da sede da Junta na Universidade de Coimbra, em 1794, desviando-a do domínio da Academia das Ciências (CARVALHO, 1986, p.497; BRAGA, 1989a, p.748 e 751) ${ }^{2}$. E em 1796 (BRAGA, 1989a, p.742) é-lhe delegado o poder de supervisionar todas as teses de doutoramento: na prática significava a censura das teses universitárias com o consequente controlo da produção científica e ideológica. $\mathrm{O}$ corolário deste processo terá sido, sem dúvida, a nomeação para o segundo reitorado em 1799, que se prolongou até 1821 e cessou a pedido do próprio (TEIXEIRA, 1889, p.7 e 12). Assim sendo, que razões levaram à sua abdicação?

Em primeiro lugar, devido à pressão interna: na Universidade várias foram as vozes contra o reitor e apesar de nunca ter ficado provado, alguns lentes e estudantes poderiam ter sido os principais incitadores (BRAGA, 1989b, p.322, 324 e 325; PROENÇA, 1955, p.166 e 167; CARVALHO, 1891, p.1). Mas a pressão também foi externa e começou pela Regência e depois da Junta do Governo Provisório e dos Deputados minando a autoridade do reitor (BRAGA, 1989b, p.309 a 311 e 312 a 315 e 333). Assim, podemos aceitar a conclusão de Teófilo Braga quando refere que o reitor foi empurrado para fora das suas funções (BRAGA, 1989b, p.343) ${ }^{3}$.

O contexto em que surge este reitorado não foi fácil também por outras razões. A nível nacional, esta foi uma época onde, em questões de ensino nos seus vários níveis, se trabalhou no sentido de uma centralização. Mas este processo foi perturbado por um acontecimento que marcou o cenário nacional, no qual a realidade universitária não foi exceção - refiro-me obviamente as invasões francesas. Este momento afetou a universidade de várias formas. Em primeiro lugar, D. Francisco de Lemos teve que se afastar da instituição, indo para França por ordem de Napoleão (após a entrada das forças francesas em Portugal). A sua estadia em França prolongou-se devido à vontade do imperador, acabando por permitir o regresso do reitor apenas em 1810. Para além disto, o próprio diaa-dia da universidade foi afetado pelas invasões. Em vários momentos, foi preciso até que se pensasse em encerrar temporariamente a universidade devido as condições adversas que se viviam no país.

Neste artigo, que não irá esquecer todo este contexto atribulado, tem então como objetivo analisar alguns aspetos deste segundo reitorado, como a atividade política e educacional de Francisco de Lemos, tal como alguns aspetos da sua gestão universitária. 
Por outro lado, nenhuma destas tarefas seria possível sem o auxílio bastante importante do seu vice-reitor, José Monteiro da Rocha, o que nos transporta para uma ideia de ação conjunta quanto aos destinos da Universidade de Coimbra. Como objeto de estudo, vou privilegiar a numerosa correspondência trocada entre ambos, privilegiando como método, uma análise detalhada de cada referência encontrada na fonte e o seu respetivo enquadramento em assuntos mais abrangentes, como se verá detalhadamente nos pontos seguintes.

\section{A Fonte}

A fonte escolhida para esta exposição foi a correspondência entre o reitor e o vicereitor, José Monteiro da Rocha, transcrita em O Instituto Revista Scientifica e Litteraria ${ }^{4}$, da qual resultaram 135 missivas - os principais interlocutores foram o lente com 109 e o prelado com 21. Quanto ao período abrangido pela fonte, inicia-se em 1799, ano de início do segundo reitorado, e prolonga-se até 1816 (Gráfico 1). E de 1799 a 1805 temos uma intensa correspondência que não encontra paralelo embora existam lacunas (1809 a 1811, 1813 e 1814) e discrepâncias.

Gráfico 1 - Dados da correspondência por ano.

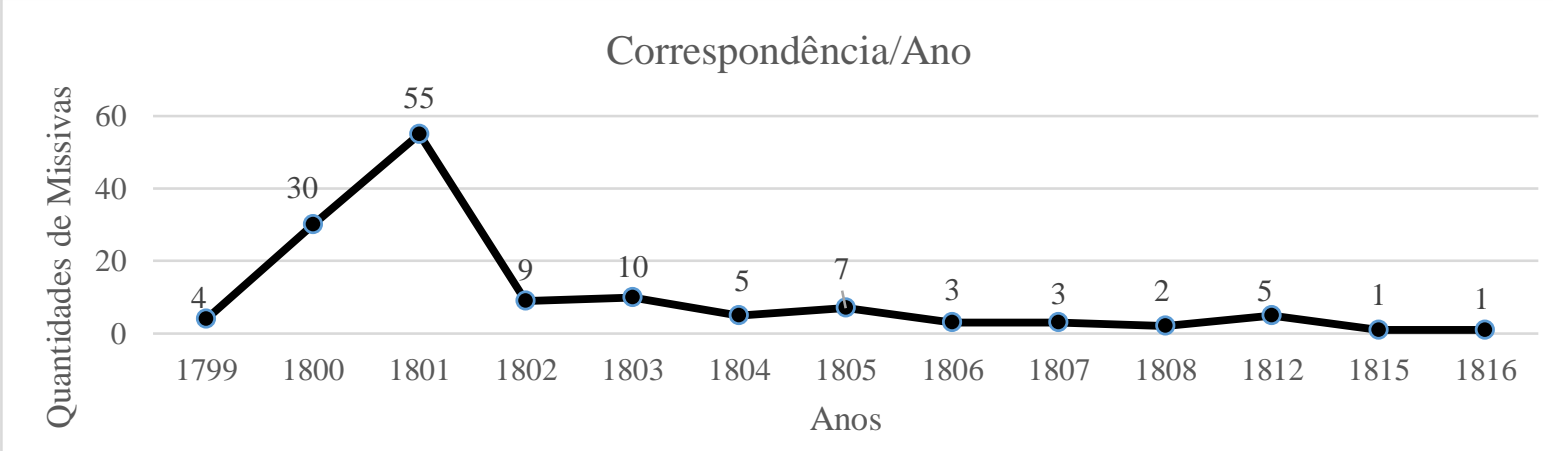

Fonte: Elaborado pelo autor.

A desigualdade dos valores anuais deve-se ao fato de D. Francisco de Lemos ter ficado em Lisboa, junto do regente, de 1799 até 1804. O que nos leva a uma clara conclusão: o governo da Universidade ficará nas mãos de José Monteiro da Rocha que informava o reitor. Mas mais duas razões têmde ser evidenciadas: a nomeação do vicereitor para Mestre do Príncipe da Beira e dos Infantes em 1804 (levando a uma drástica descida no número de cartas) e o facto de o prelado ter estado refém de Napoleão em França (de 1808 até 1810, só voltará a Coimbra em 1814). Quanto ao método de análise usado, foi necessário incluir as várias referências encontradas nas missivas em assuntos mais abrangentes e por fim, em grupos: 18 assuntos englobados em dois grupos. E para tratar a correspondência existiram pelo menos dois correios que mantinham esta intensa ligação (embora não por muito tempo): em 1801, queixava-se o vice-reitor de que a desorganização o obrigou a reenviar alguma da sua correspondência ${ }^{5}$.

O primeiro grupo (A importunância das questões externas)abrange assuntos como: a Junta da Diretoria Geral dos Estudos, as Invasões Francesas, Benesses, Subsídio Literário, Saúde Pública e a Junta dos Três Estados. Já o segundo (A vida universitária onde se insere também A parte Administrativa)engloba os seguintes temas: Lentes, Aulas, Disciplina, Compêndios, Desenvolvimento Científico, a Representação Institucional, Funcionários, Cerimonial, Jardim Botânico, Administração e Obras. Sendo importante, esta fonte tem naturais limitações: o seu caráter não sistemático e irregular no tempo e a 
discrepância entre emissários. Mas, para o período que cobre melhor, permite traçar um quadro dos principais problemas da Universidade.

\section{A Importância Das Questões Externas}

\section{O ensino secundário}

Esta fonte foi capaz de nos oferecer informações sobre dois assuntos bastante importantes: a Junta da Diretoria Geral dos Estudos e Escolas destes Reinos (42 referências - 1800 à 1803) e o Subsídio Literário (6 referências - 1800, 1801 e 1803). A Junta, criada em 1794, vem substituir a Real Mesa sobre o Exame e Censura dos Livros (CARVALHO, 1986, p.495) e ficou a cargo da Universidade de Coimbra - ficando o reitor como seu presidente ${ }^{6}$. Esta, inicialmente, careceu do seu presidente - que esteve em Lisboa até 1804 - e no seu lugar ficou José Monteiro da Rocha que esteve em contínuo contacto levando assim a concluir que este trabalho foi uma tarefa partilhada (PROENÇA, 1955, p.88). Mas a distância também foi benéfica: em Lisboa, o reitor e presidente, estava próximo do Regente e assim poderia intervir, junto deste, sobre qualquer decisão tomada entre si e o vice-reitor. Quanto aos muitos tópicos dentro deste assunto destacam-se os seguintes: a nomeação dos indivíduos para os cargos de direção, a escolha dos professores e os vencimentos ${ }^{7}$. Quanto ao primeiro - que podemos apelidar de monopolização dos membros da Junta - tem de ser compreendido como uma forma de controlar a instituição e também de a tornar mais dependente da Universidade. O processo de recrutamento dos seus membros foi o seguinte: o pretendente era decidido pelos dois responsáveis (reitor e vice) e depois o seu nome era apresentado numa reunião da Juntae aqui, visto que o reitor estava ausente, competia ao vice exercer a sua influência para que o proposto fosse favoravelmente votado. Mas o procedimento só era finalizado quando o reitor o oficializasse em provisão (O INSTITUTO, 1888 e 1889, p.372). Em 1800 e 1801 surgem os primeiros eleitos: António Ribeiro dos Santos (escolhido pelo reitor) passou a Deputado Comissário de Lisboa (O INSTITUTO, 1888 e 1889, p. 310) ${ }^{8}$, Fr. Joaquim de Santa Clara para Deputado (escolhido pelo vice-reitor) (O INSTITUTO, 1888 e 1889, pp, 588 e 589) ${ }^{9}$, e Joaquim dos Reis também para Deputado - já em 1801 e muito provavelmente pela iniciativa do lente - (O INSTITUTO, 1888 e 1889, p.660). Mas nem todas as nomeações foram pacíficas, a escolha de Fr. Jerónimo trouxe alguma discussão e este foi claramente favorecido pelo vice-reitor (O INSTITUTO, 1888 e 1889, p.453) ${ }^{10}$.

Quanto à escolha dos professores (cujo processo não era muito diferente) o lente começa logo por definir que deveriam ser seculares e graduados pela instituição coimbrã (O INSTITUTO, 1888 e 1889, p.590). Segundo o mesmo, esta decisão prendia-se com: a qualidade, a vontade de motivar os alunos da Universidade - que teriam assim uma saída profissional - e acentuaria o monopólio que a instituição superior exercia sobre o ensino secundário. Quanto aos alunos é necessário fazer um reparo: não seriam aqueles que mais se destacariam na Universidade - pois a estes seria reservada a docência no ensino superior - mas seriam aqueles que ficassem logo a seguir aos mais capazes. Já os critérios foram logo executados nas primeiras nomeações - propostas pelo lente - de Francisco Xavier Monteiro de Barros e Martim Ribeiro Andrade (O INSTITUTO, 1888 e 1889, p.590 e 591). Mas este controlo no recrutamento arrastou-se aos próprios concursos: os interessados eram escolhidos cautelosamente nas reuniões da Junta mas o acesso à respetiva cadeira era discutido bem antes pelas chefias. Assim foi com Henrique Henriques em 1801 para a cadeira de Retórica (O INSTITUTO, 1888 e 1889, p.658), e em 1802 com João António Ferreira para Guimarães e Francisco Xavier para Rebordães (O INSTITUTO, 1889 e 1890, 
p.274) $)^{11}$. Na fonte ficou também evidente um caso onde um professor, após o percurso na via secundária, acabou por ganhar o seu lugar na Universidade para lecionar grego - valeu a qualidade e a experiência demonstrada no Porto (O INSTITUTO, 1889 e 1890, p.562).

$\mathrm{O}$ assunto dos vencimentos também foi bastante debatido, a fonte de rendimento deveria ter sido o Subsídio Literário mas assim não aconteceu: este acabou por ser desviado para outras finalidades pelas mãos do Real Erário o que levou a vários problemas relativos aos ordenados de mestres, professores e deputados (CARVALHO, 1986, p.497). Em 1800 ainda restavam dúvidas relativamente aos vencimentos e a forma de recolha do subsídio. Quanto ao primeiro, o vice-reitor entendia que seria necessário um aumento de 50 mil reis e a equidade dos ordenados dos professores, independentemente da zona onde lecionavam (O INSTITUTO, 1888 e 1889, p.514) ${ }^{12}$. Mas quanto a esta isenção não foi possível encontrar mais referências; e relativamente aos ordenados dos deputados, do contador, tesoureiro e escriturários foi possível ver um novo pedido de aumento em 1803, feito pelo vice-reitor (O INSTITUTO, 1889 e 1890, p.561). Relativamente à forma de recolha - que o vice-reitor repudiava completamente - era feita através de rendeiros que, segundo ele, não passariam de predadores cuja margem de lucro delapidava o trabalho de quem devia pagar o dito tributo ${ }^{13}$.

A isenção do imposto da décima - para os professores da Junta - também foi discutida e entendeu o vice-reitor que o melhor a fazer seria mesmo aumentar os ordenados e que não se ordenasse a isenção do dito imposto (O INSTITUTO, 1888 e 1889, p.657). Sem dúvida, pretendia o melhoramento desta carreira - devido à sua importância nacional e o equilíbrio entre as clivagens dos vencimentos (O INSTITUTO, 1889 e 1890, p.204) ${ }^{14}$. Quanto ao vencimento dos deputados, estabelecido por José Monteiro da Rocha (O INSTITUTO, 1889 e 1890, p.661 $)^{15}$, também se levantou o problema da décima. O dilema estaria em definir se estes se deveriam incluir no corpo académico: a inclusão iria isentálos de tal obrigatoriedade, visto que já pertenceriam ao corpo universitário se bem que agora se encontravam com uma função distinta. Mas quanto a esta isenção não foi possível encontrar mais referências; e relativamente aos ordenados dos deputados, do contador, tesoureiro e escriturários foi possível ver um novo pedido de aumento em 1803, feito pelo vice-reitor (O INSTITUTO, 1889 e 1890, p.561).

Um outro problema prendia-se com a forma de pagamento e é logo em 1801 que o lente define o processo: deveria a Junta enviar as folhas de pagamento para os provedores das comarcas que por sua vez procederiam ao pagamento e depois enviavam as folhas para o Erário onde seriam reembolsados pelo pagamento aos professores (O INSTITUTO, 1888 e 1889, p.592). Mas a falta de eficácia e o atraso no decreto de regularização levou uma resistência no pagamento por parte dos provedores (O INSTITUTO, 1888 e 1889, p.657 e 658) e em 1803 o procedimento é eliminado e a responsabilidade do pagamento passa do Erário para a Junta (subsidio da comarca) (O INSTITUTO, 1889 e 1890, p.563). E se na forma de recolha nada se inovou, o que de novo levou a críticas por parte do vice-reitor, o mesmo já não aconteceu com o recetor da dita verba que então passou a ser a Universidade (O INSTITUTO, 1888 e 1889, p.512 e 513) ${ }^{16}$. A necessidade de fazer chegar diretamente o subsídio a Universidade foi acima de tudo uma lição bem aprendida: desta forma não seria possível desviar a dita contribuição para qualquer outro fim (O INSTITUTO, 1889 e 1890, p.271). Muito provavelmente as verbas recolhidas não seriam suficientes, e o próprio lente refere que se deveria aumentar ao imposto. Em 1803, volta-se a falar de uma outra contribuição, um donativo extraordinário (O INSTITUTO, 1889 e 1890, p.624). Embora não fosse possível encontrar mais nenhuma referência, podemos concluir que este poderia ter como objetivo as despesas da Junta.

Outro dos problemas foi a constante disputa com Lisboa. O vice-reitor entendeu 
que o erro nos editais publicados em Lisboa ${ }^{17}$ - onde constava apenas a firma do comissário dessa cidade - não era mais do que uma ameaça e propõe isenção dos estudos em Lisboa. No seu entender, esta separação iria impossibilitar uma futura submissão da Junta e da Universidade à capital (O INSTITUTO, 1888 e 1889, p.372 e 373) ${ }^{18}$. Para o lente esta ação não seria mais do que legitimar o que na prática já se realizava. Mas o que acima de tudo pretendia seria tirar deste conjunto um dissidente, para desta forma a Universidade continuar a sua cruzada em controlar todas as instituições de ensino do reino sem qualquer oposição ${ }^{19}$. Mas o problema não ficou por aqui e pouco depois foi entregue, pelas mãos de António Ribeiro dos Santos, uma proposta que estipulava várias regras para o governo da Junta $^{20}$. Mas esta estava longe de agradar ao vice-reitor, pois, diminuía os poderes do presidente (O INSTITUTO, 1888 e 1889, p.453 e 454). E em 1801, é o próprio Monteiro da Rocha que apresenta uma medida completamente oposta à anterior: propõe que as cartas dos professores nomeados passassem diretamente para as mãos do reitor visto que estava próximo do Regente e após lhe dar conhecimento só a ele (reitor) competia assiná-las (O INSTITUTO, 1888 e 1889, p.591 e 592; PROENÇA, 1955, p.90). Já a questão do ensino no ultramar e o domínio que os bispos e governadores tinham - nas suas respetivas áreas - nesta matéria, teve que ser repensada. Mas, segundo o vice-reitor, e para não alimentar mais contendas desnecessárias, foi preferível esperar pela promulgação da lei que cederia a jurisdição do ensino á Junta ${ }^{21}$.

Outra conclusão que podemos retirar da fonte é a de que os dirigentes da Junta compreendiam este empreendimento como uma clara necessidade nacional e nesse sentido não perderam nenhuma hipótese de ampliar a sua jurisdição. O primeiro foi José Monteiro da Rocha, que em 1800, pede ao reitor que não se perdesse a oportunidade de trazer para a direção da Junta o Colégio dos Nobres - antecipando-se aos estudos de Lisboa - (O INSTITUTO, 1888 e 1889, p.588; PROENÇA, 1955, p.91) $)^{22}$. E o próprio reitor, tendo em consideração a união da Igreja com o Estado só possível através da instrução pública, ordena que em todas as dioceses e comarcas do reino se criassem os estudos eclesiásticos ${ }^{23}$.

\section{O perigo francês e as invasões}

Como seria inevitável um dos temas incontornáveis deste período foram as Invasões Francesas: com 36 referências - de 1799 a 1801 e de 1807 a 1812 - foi o segundo assunto mais discutido. Mas nesta exposição não importam tanto os conflitos em si, mas a posição dos principais responsáveis da Universidade de Coimbra em relação a este momento político e bélico. Desta forma, as preocupações dividem-se em dois momentos: o primeiro ligado a uma inquietação nacional onde a realidade portuguesa, as suas necessidades perante este acontecimento e o seu lugar no xadrez internacional foram muito discutidas; e em segundo os desassossegos locais - centrados na cidade de Coimbra. Quanto ao primeiro momento fica evidente a posição do vice-reitor: crítico do contexto internacional - talvez já perspetivando as consequências para Portugal - afirma que se deveria optar por uma certa neutralidade, colocando em causa a relação luso-inglesa (O INSTITUTO, 1888 e 1889, p.306). Relativamente ao seu objetivo principal foi mesmo a procura da paz de uma forma geral e bem mais abrangente do que o simples contexto nacional ${ }^{24}$. Desconfiado dos dois lados que então circundavam Portugal, França e Inglaterra, torna-se claro quanto à sua própria preferência pelos gauleses (O INSTITUTO, 1888 e 1889, p.450). Mas o seu pensamento é bem mais complexo e até talvez utópico: o lente sugeria que se aceitasse a proposta de Napoleão - mas que esta fosse também uma aliança ofensiva e defensiva - e a histórica relação entre Portugal e Inglaterra deveria ser abandonada - de forma a que os 
britânicos não nos vissem também como um inimigo. Mas logo depois o próprio refere que tal aliança é impossível e em 1801, menciona que se começasse então a tratar de uma aliança com Castela (O INSTITUTO, 1888 e 1889, p.734 e 735). Formando assim uma península unida capaz de não só tentar fazer frente a ameaça napoleónica como também de não ficar refém de fracos aliados. Mas esta vontade em tentar algum acordo acaba por desaparecer devido ao desenrolar dos acontecimentos ${ }^{25}$. Já segundo o lente um outro problema estaria também a contribuir para esta nefasta situação: a instabilidade aliada a alguma incompetência interna. Começa por criticara inércia total de Lisboa (O INSTITUTO, 1888 e 1889, p.659 e 660; BRAGA, 1989b, p.246), a falhada tentativa de acordo em 1801 com o envio de um representante português a Paris (O INSTITUTO, 1888 e 1889, p.734) e a ida para o Brasil por parte do Regente e da família Real - o que para si significaria a perda do reino por parte do próprio Regente (O INSTITUTO, 1888 e 1889, p.735; BRAGA, 1989b, p.249).

Foi também possível encontrar referências específicas à cidade de Coimbra dentro deste contexto. Ainda antes do conflito houve movimentação de tropas, o que se repercutiu na cidade que em 1801 recebeu o exército do Norte: o que não agradou ao vice-reitor que se manifestou adverso a esta medida por colocar lado a lado estudantes e soldados (O INSTITUTO, 1889 e 1890, p.55). Com a vinda de quatro regimentos para a cidade e a má organização resultante do acomodamento dos soldados depressa levou a que o lente se queixasse das confusões (O INSTITUTO, 1889 e 1890, p.56) ${ }^{26}$.

Nas missivas também foi possível ver que, no segundo dos períodos aqui considerados, sob as ordens do reitor, o lente ordenou que uma deputação académica fosse incumbida de saudar Junot embora também ficasse evidente que isto não agradou a todos (O INSTITUTO, 1889 e 1890, p.804). Mas este ato não foi isolado: o próprio vice-reitor já teria até pedido ao reitor que tivesse enviado os lentes que se encontrassem em França para cumprimentarem Napoleão (BRAGA, 1989b, p.284). Mas quanto a estas medidas podemos apenas dizer que pouco mais havia a fazer e que a posição do reitor teria talvez mais em conta não uma submissão mas uma clara vontade em proteger a Universidade.

\section{Benesses}

Este assunto (14 referências) diz respeito às benesses com que alguns foram brindados. E se o maior beneficiado foi mesmo José Monteiro da Rocha, podemos logo concluir que tal como Pombal se preocupou em promover os seus (sendo o reitor apenas um desses, basta ver o período de 1761 até 1775) o mesmo aconteceu com D. Francisco de Lemos neste seu segundo reitorado. E o facto de este ter ficado em Lisboa durante tempo considerável funcionou de forma clara para influenciar os privilégios recebidos pelo lente de Matemática. Quanto às mercês podemos ver que o caminho começa logo a fazer-se em 1799 quando vaga uma comenda em Portalegre e o vice-reitor depressa avisa o reitor do sucedido - muito provavelmente para se adiantar a ouros possíveis candidatos. Mas o que com isto conseguiu foi mesmo o iniciar do processo que acabaria por lhe entregar a dita comenda. Desta forma começa então o prelado a exercer a sua influência para garantir a dita atribuição, que segundo o lente não seria mais do que uma justa recompensa não só do seu trabalho, mas também tendo em conta algumas outras nomeações que foram entendidas como ofensivas para o mesmo ${ }^{27}$. E em 1801 as movimentações dão o resultado desejado e o vice-reitoré então agraciado com a comenda e como o próprio referiu, em muito a ficou a dever ao reitor (O INSTITUTO, 1888 e 1889, p.662; BRAGA, 1989b, p.246). Também no mesmo ano começa a ser fabricada mais uma forma de privilegiar o lente, desta vez para Mestre do Infante - mas foi necessário agir com alguma cautela (O INSTITUTO, 1888 e 
1889, p.797; BRAGA, 1989b, p.250 e 251). Por essa mesma altura, o reitor deveria ter pedido ao lente que o acompanhasse em Lisboa mas este refere que temia fazê-lo por pensar que poderia prejudicar o seu acesso ao cargo ${ }^{28}$. Mas todos os cuidados acabaram por surtir o efeito pretendido e em 1804 Monteiro da Rocha dirige-se para Lisboa para tomar posse do seu novo cargo (O INSTITUTO, 1889 e 1890, p.476). Para além do lente de Matemática, temos uma referência a José Telles que acabou por ser despachado para a Junta dos Três Estados por ordem do reitor em $1805^{29}$. Outras vacaturas foram identificadas (abadia de S. Romão de Vila Cova de Vez e Igreja de S. Martinho de Alvaredo) durante a análise embora as informações recolhidas não nos permitam concluir quem terá beneficiado das mesmas. Mas nestes casos o vice-reitor apenas se limitou a informar o prelado das vagas preferindo aguardar pela decisão do seu superior (O INSTITUTO, 1889 e 1890, p.561 e 563).

\section{A questão médica}

O assunto aqui em evidência, Saúde Pública, engloba o conselho médico e o protomedicato e tem por base as breves referências (3) encontradas na fonte estudada. A primeira iniciativa partiu do reitor quando, em 1801, propôs a criação de um Conselho Médico na Universidade(O INSTITUTO, 1888 e 1889, p.794) ${ }^{30}$. Esta ideia foi bem acolhida pelo lente que via nela uma forma de reanimara faculdade de Medicina mas também uma clara ideia de oposição (ou de sobreposição) a Lisboa: pretendia assim que esta nova criação fosse oposta, embora de género idêntico, à da capital onde reinaria a corrupção nos tribunais de saúde (O INSTITUTO, 1888 e 1889, p.794). E propunha medidas que visavam não só uma submissão do novo corpo àUniversidade mas também, tornar o reitor como a autoridade máxima do novo Conselho (O INSTITUTO, 1888 e 1889, p.795; PROENÇA, 1955, p.107). Quanto à organização administrativa o lente tratou logo da nomenclatura e da quantidade dos cargos de direção ${ }^{31}$ : por parte do lente notou-se uma clara pressa para que o projeto se concretizasse, muito provavelmente por ter entendido este como uma forma clara de dignificar ainda mais a Universidade. E é logo no mesmo ano que avisa o reitor que seria necessário começar a promover indivíduos para os cargos definidos $^{32}$ - indicou também para a necessidade de se guardar segredo acerca destas diligências para evitar contendas com Lisboa, que não seriam benéficas para a conclusão do projeto.

Mas ainda no âmbito desta temática surge uma outra ideia, a da criação de um Protomedicato: esta ideia não era inovadora no contexto nacional, uma vez que já fora criado um outro Protomedicato, instalado em Lisboa que datava de $1782^{33}$. Naturalmente que a instituição de que agora falamos é outra que começa a ser pensada durante o segundo reitorado de D. Francisco de Lemos. É no âmbito da ideia do Conselho Médico que surge a sugestão do vice-reitor, a qual pretende complementar a ideia do prelado com a sugestão de dar ao protomedicato da Universidade a jurisdição do distrito de Coimbra (em matéria de

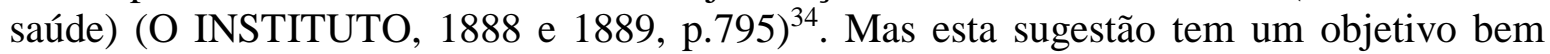
mais amplo: pretendia-se que, lentamente, este órgão da instituição universitária fosse aumentando a sua alçada sob toda a matéria de saúde pública no reino. Esta sugestão foi aceite pelo reitor que em 1805, no esboço de regulamentação que enviou a Monteiro da Rocha, tratou também de fazer algumas alterações: ligar a Universidade ao Protomedicato, referindo que os lentes deveriam ser os deputados e que poderiam ser eleitos pelo reitor $(\mathrm{O}$ INSTITUTO, 1889 e 1890, p.711). D. Francisco de Lemos partilhava da mesma preocupação do lente e entendia que esta criação poderia gerar algum desconforto em Lisboa e logo avisou que tudo se deveria fazer com a devida cautela. Mas apesar de todos 
estes esforços o reitor não conseguiu levar os seus intentos por diante (PROENÇA, 1955, p.107). Muito provavelmente porque os tempos não fossem de novas criações mas sim de medo e preocupação devido à grande ameaça externa.

\section{A Vida Universitária}

\section{O ensino}

\subsection{Lentes}

A questão dos lentes foi dos assuntos mais debatidos - 31 referências de 1800 até 1807 e 1815 a 1816 -, sendo possível determinar vários temas específicos: jubilações, docentes propostos, o envio dos catálogos dos lentes para Lisboa, provimento através de concurso e de dissertações, os ordenados e concessões. Mas o que também fica patente é que o vice-reitor teve um papel ativo devido à sua proximidade com a Universidade e com quem nela trabalhava, escolhendo pessoalmente alguns lentes e substitutos. As primeiras referências dizem respeito a aposentações: em 1800, o vice-reitor pediu a jubilação de dois lentes que não estariam à altura das exigências - o problema estava no valor da aposentadoria (O INSTITUTO, 1888 e 1889, p.307) ${ }^{35}$, e em 1801, pela mesma razão, faz pedido idêntico (Félix José Marques na cadeira de Filosofia Racional e Moral) (O INSTITUTO,1889 e 1890, p.199) ${ }^{36}$. Mas a incompetência não foi o único critério esgrimidopelo lente para propor a jubilação de alguns professores ${ }^{37}$ - a desconfiança e a discórdia também levaram a saídas. José Pinto, médico no hospital mas que exercia também a clínica fora dele, foi indicado pelo vice-reitor para a jubilação por estar em pleno desacordo com a sua conduta - pesavam também acusações de corrupção e fraude que em muito ajudaram o lente em indicá-lo como dispensável (O INSTITUTO, 1889 e 1890, p.560). Quanto às reformas forçadas as coisas não foram assim tão fáceis: alguns dos indesejados teriam ligações importantes que resultaram em entraves intransponíveis. Isso mesmo se pode ver numa missiva do prelado datada de 1805 onde é o próprio que trata de suspender a jubilação (O INSTITUTO, 1889 e 1890, p.711 e 712). Para além destas razões, outras de cariz bem menos severo importavam para promover a saída de alguns docentes: o bom desempenho associado à idade e o estado de saúde. Quanto ao primeiro temos os exemplos de Manuel Barreto (O INSTITUTO, 1889 e 1890, p.338) ${ }^{38}$, e mais tarde, em 1816, nova indicação se dá para outro lente (O INSTITUTO, 1889 e 1890, p.884). Quanto à motivos de saúde, podemos apontar um caso em 1816 - mas na fonte foi possível encontrar várias referências da fraca saúde de vários lentes (O INSTITUTO, 1889 e 1890, p.884).

Após as jubilações era necessário prover os lugares vagos e a maioria dos indicados pertenceu a José Monteiro da Rocha. Em 1800 propõe a composição da faculdade de Matemática (na sequência de um provável despacho de um lente para um cargo fora da faculdade) (O INSTITUTO, 1888 e 1889, p.449) e indica também alguém para lente embora neste caso não fosse possível definir qual a faculdade que o iria recolher. Mas o que ficou visível foi o peso da opinião do vice-reitor que, se houvesse dúvida entre candidatos tinha voto decisivo (O INSTITUTO, 1888 e 1889, p.512). Em 1801 o lente trata de indicar vários pretendentes: para Matemática Agostinho José Pinto (substituto) e Manuel José da Cunha e Sousa e Agostinho José Pinto de Almeida (ajudantes), para Medicina os irmãos Navarro (Vicente Navarro de Andrade e Sebastião Navarro de Andrade) e Santa Bárbara (O INSTITUTO, 1889 e 1890, p.53) e para lente de Filosofia o Padre Emídio (O INSTITUTO, 1889 e 1890, p.131 e 199). Em 1803 a faculdade de Medicina volta a deparar-se com uma vaga respeitante à cadeira de Prática sendo proposto para docente João de Campos $(\mathrm{O}$ 
INSTITUTO, 1889 e 1890, p.562). Estas escolhas só se efetivaram depois da aprovação do Reitor que continuava a ter a última palavra (embora não fosse possível encontrar nenhum caso de discordância), na aprovação dos despachos para a admissão dos propostos. Para além disso, encontra-se uma indicação do prelado para duas escolhas embora não especificasse se seria para lentes, substitutos ou ajudantes (O INSTITUTO, 1889 e 1890, p.712); e uma, mais explícita, de Francisco Xavier para Demonstrador de Anatomia (O INSTITUTO, 1889 e 1890, p.714) - mas foram casos excecionais. Outra forma de tratar do provimento foi através de concurso embora o que parece evidente é que esta alternativa seria apenas uma segunda opção: usada em caso de nenhum dos dois ter conseguido propor alguém.

É já quando está para deixar a Universidade (1 de dezembro de 1804) que Monteiro da Rocha elabora um alvará pelo qual se deveriam reger os futuros concursos restringindo o acesso à categoria de opositor e obrigando estes a redigir uma dissertação anual, como elemento curricular decisivo (BRAGA, 1989b, p.267 a 271). Quanto às dissertações parecem ter despertado algum interesse por parte do lente e do reitor que se mostravam ansiosos pelos resultados, visto que a sua elaboração podia ser decisiva para chegar a conclusões bastante importantes: o merecimento dos candidatos, determinados comportamentos ideológicos e proporcionar também um importante barómetro que iria medir a própria qualidade do ensino praticado na instituição (O INSTITUTO, 1889 e 1890, p.800 e 801).

Mas nesta tarefa de promoção de lentes também foi possível encontrar um importante obstáculo, a falta de gente com competências suficientes ${ }^{39}$ : assim aconteceu com a recém-criada cadeira de Metalurgia - onde já se teria encontrado o lente - mas como era necessário que este dominasse conhecimentos só possíveis de adquirir no estrangeiro, partiu às custas da Universidade. Mas o problema estaria em quem o iria substituir durante a sua ausência, o que acabou por levar a uma crise tal que o vice-reitor sugeriu que se procedesse a anulação da cadeira e que esta continuasse a ser ministrada como antes juntamente com Química (O INSTITUTO, 1889 e 1890, p.338). Em 1805, volta a aparecer um problema semelhante: o lente queixou-se de que continuariam a existir vagas em três faculdades e que nem o recurso ao concurso foi capaz de produzir efeitos positivos. A falta de pretendentes capazes foi evidente, como comenta o reitor, em resposta, ao dizer que muitos haviam desistido (O INSTITUTO, 1889 e 1890, p.710).

Neste assunto foi também possível encontrar referências quanto aos vencimentos dos docentes e aqui o vice-reitor volta a ter um papel decisivo: não só definiu alguns valores, mas também demonstrou uma grande preocupação com a equidade $(\mathrm{O}$ INSTITUTO, 1888 e 1889, p.661). E para além deste critério pesou também a qualidade dos lentes: José Monteiro da Rocha levou este ponto sempre em conta (O INSTITUTO, 1889 e 1890, p.54). Mas o lente acaba também por realizar um interessante pedido ao reitor em 1800 e que podemos denominar de concessões: pretendia que se tratasse de garantir um lugar a um teólogo - lente da Universidade - na Mesa da Consciência, como se praticara com os juristas relativamente ao Desembargo do Paço (O INSTITUTO, 1888 e 1889, p.587). A razão invocada é a de que assim se incentivariam os lentes teólogos, mas não será demasiado ousado pensar que esta admissão de alguém ligado à instituição, provavelmente proposto pelo reitor, era uma forma de estender a influência da Universidade a outras importantes instituições.

No desempenho das suas funções correntes não se descuidou o vice-reitor, tal como acontecia com as matrículas dos estudantes, de enviar todos os anos os catálogos dos Lentes para o Reitor em Lisboa. 


\subsection{Aulas}

Nesta temática pretende-se expor uma das principais preocupações relativas ao ensino: as aulas (19 referências de 1799 até 1801 e em 1805). E aqui foi possível detetar temas mais específicos: os melhoramentos em alguns cursos, as matrículas, as avaliações, mas também o problema da suspensão das aulas devido as Invasões.

Quanto ao primeiro, esta ligado às faculdades jurídicas, a Matemática e a Teologia $^{40}$. E é o vice-reitor que começa logo a reagir a uma medida que consistia em retirar a Retórica do plano de estudos dos juristas - no seu entender, a matéria em questão era essencial pois seria a continuação e aperfeiçoamento do latim (O INSTITUTO, 1888 e 1889, p.305). E embora não fosse possível encontrar a resolução do problema, as preocupações com os cursos jurídicos persistiram. Em 1802 o lente envia ao prelado o plano sobre as cadeiras comuns de Cânones e Leis onde se estipulou também quais os lentes e os compêndios (O INSTITUTO, 1889 e 1890, p.477). O mesmo assunto reaparece em 1805 e, desta vez por parte do reitor, também fica bem clara a sua ação: definido então o plano por José Monteiro da Rocha coube ao reitor tratar da aprovação - e apesar de uma dura oposição do Conde de Vila Verde os melhoramentos realizaram-se (O INSTITUTO, 1889 e 1890 , p.709 e 710) ${ }^{41}$. A outra faculdade que requereu a atenção do reitor foi a de Matemática, criando duas novas cadeiras, Hidráulica e Astronomia, que rapidamente foram despachadas pelo vice-reitor (O INSTITUTO, 1988, 1889,1890, p.592; PROENÇA, 1955, p.102). E logo depois, para as mesmas cadeiras, D. Francisco de Lemos volta a ser decisivo, garantindo a permissão régia para a concretização do projeto (O INSTITUTO, 1888 e 1889, p.54). No caso de Teologia também ficou patente a ideia de que se pretendiam algumas alterações - mas as referências foram demasiado incipientes (O INSTITUTO, 1889 e 1890, p.711). Mas a vontade do prelado em continuar a beneficiar a suainstituição estendeu-se a outras matérias, como o observatório: em 1799 tratou de enviar para a Universidade o regulamento que definia a forma de funcionamento (O INSTITUTO, $1888 \mathrm{e}$ 1889 , p.307), mas devido aos atrasos o vice-reitor, em 1801, pede que este se publique (O INSTITUTO, 1889 e 1890, p.54).

Ainda neste tema foi possível ver que a ação do vice-reitor foi bastante importante na comunicação de informações relativas as matrículas e aos atos (O INSTITUTO, 1888 e 1889, p.658). E uma das suas medidas mais interessantes foi a de decidir fazer uma relação de todos os alunos matriculados - nas faculdades e no Colégio das Artes - para desta forma até os pais dos mesmos conseguirem seguir o percurso dos estudantes (O INSTITUTO, 1888 e 1889 , p.587) ${ }^{42}$. Podemos ver também que o reitor, apesar de longe, participaria diretamente nas admissões: em 1800 envia duas petições relativas a dois frades para Monteiro da Rocha e este, por sua vez, tratou de efetivar a matrícula dos mesmos. E a julgar pelas palavras do lente estes não seriam caso único (O INSTITUTO, 1888 e 1889, p.587). Quanto às avaliações a maioria das referências demonstram-nos apenas a tarefa informativa do lente embora fosse possível identificar alguns dos problemas com que se debateu. O primeiro de todos foi a ausência da oficialização dos despachos de professores que pudessem argumentar nos atos: este, que afetava a faculdade de Leis, arrastou-se durante a época avaliativa de 1800 (O INSTITUTO, 1888 e 1889, p.509 a 511) ${ }^{43}$. No mesmo ano, o reitor alertou para o problema que poderia resultar do facto de alguns frades se poderem graduar em filosofia ou em matemática - esta preocupação era partilhada por ambos e devia-se ao fato de estes ainda estarem ligados a antiga escolástica (O INSTITUTO, 1888 e 1889, p.510; BRAGA, 1989b, p.245).

Mas algo mais grave estaria no horizonte, o início do século trouxe consigo movimentações bélicas (Guerra das Laranjas, maio e junho de 1801) que por sua vez 
levaram à discussão quanto ao fecho das aulas durante um ano, a ideia parece até ter sido do reitor mas o lente foi desde cedo um firme opositor ${ }^{44}$ : receava que os estudantes, livres dos estudos, pudessem perder-se tendo em conta os acontecimentos que então se apresentavam e que não seria aconselhável suspender as aulas. $\mathrm{O}$ principal temor seria mesmo o de não dar espaço, nem razões, àqueles que eram inimigos da Universidade ${ }^{45}$. $\mathrm{O}$ assunto foi de novo mencionado (20 de setembro de 1801) mas desta vez já não se referia a uma pausa anual, mas apenas até ao Natal e de novo o vice-reitor reage firmemente: receava que a suspensão se tornasse anual e isso se manifesta-se nos cofres da instituição (O INSTITUTO, 1889 e 1890, p.129). E chama também a atenção para que a decisão final fosse tomada rapidamente, evitando assim uma jornada inútil aos estudantes. A Universidade só acabou por ser fechada quase uma década mais tarde (devido a violência da invasão francesa), ficando encerrada de 10 de setembro de 1810 até 23 de setembro do ano seguinte (RODRIGUES, 1990. p.179 e 180).

\section{3. Compêndios e publicações}

A questão dos compêndios teve uma percentagem bastante reduzida de apenas 6 referências (1801, 1802, 1804 e 1805). Aqui foi possível ver a indicação de obras - o vicereitor propôs e direcionou algumas obras enquanto o prelado só o fez uma vez, embora todas tivessem que passar pelo reitor - e o peso da censura.

Será interessante assinalar que uma primeira comunicação de Monteiro da Rocha diz respeito a um "plano do Bibliothecario para as Correspondencias Litetrarias e remessas de livros periódicos", o que nos coloca perante o intercâmbio de publicações científicas que careceu da aprovação do reitor, necessária para o respetivo apoio financeiro $(\mathrm{O}$ INSTITUTO, 1888 e 1889, p.589). Em dezembro 1802, é uma outra publicação que se anuncia, a Ephemeride Astronomica, que o próprio Monteiro da Rocha estaria a preparar para publicação em 1804 (O INSTITUTO, 1889 e 1890, p.476). Na mesma carta, o vicereitor, correspondendo a um pedido do reitor, envia uma relação pormenorizada das cadeiras da faculdade de Leis, dos respetivos professores e dos compêndios a serem utilizados. A última indicação data já de 1805 e diz respeito também aos cursos jurídicos: e o lente propõe os Elementos de Direito Civil de Heinécio - segundo o reitor, esta estaria já pura e reformada, ou por outras palavras censurada - (O INSTITUTO, 1889 e 1890, p.711 $)^{46}$. Esta prática foi também possível ser encontrada num outro caso. Em 1802, Fr. Joaquim de Azevedo prepara uma obra, em dois volumes, sobre os "logares dos livros históricos da Escriptura", que submete à Congregação da sua faculdade. Tratava-se de uma obra polémica "em que os incrédulos modernos têm repisado as objecções dos antigos", e após "muitas e longas congregações" não se havia chegado a acordo quanto à sua aprovação. Sendo este episódio bem elucidativo relativamente ao funcionamento do escrutínio científico (e também ideológico) da produção dos professores da Universidade. Mas a longa espera fez com que o autor retirasse a obra e a levasse consigo quando se ausentou para Lisboa: o que levou o vice-reitora contar o sucedido ao reitor, pedindo que ele próprio procedesse a analise da obra quando esta lhe fosse apresentada (O INSTITUTO, 1889 e 1890, p.273).

\section{4. Uma rígida disciplina}

$\mathrm{O}$ assunto aqui em evidência prende-se com a rigorosa política de disciplina que ambos procuraram aplicar a todo o corpo académico (6 referências). Neste tema foi possível fazer uma divisão em três momentos: o comportamento dos alunos em relação à cidade e à Universidade, e por fim, as faltas de alguns funcionários. E se o grosso das 
informações se prende com o primeiro caso, em todos foi possível ver que em ocorrências de indisciplina o primeiro a atuar foi o vice-reitor - o que é justificado pela proximidade mas também pela gravidade das infrações perpetradas - embora sempre tivesse esperado pelas conclusões do reitor. O primeiro relato sobre possíveis desacatos com alunos data de 1801 e refere um provável envolvimento destes num diferendo entre o Juiz do Crime e o Juiz do Povo: Monteiro da Rocha põe em dúvida que estes eram realmente estudantes $(\mathrm{O}$ INSTITUTO, 1888 e 1889, p.659). Mas mais grave terá sido a confrontação, ocorrida em 25 de março de 1801, entre estudantes e milicianos (à época o exército do Norte estacionava em Coimbra) e que resultou numa Devassa por parte do Desembargador Conservador (O INSTITUTO, 1889 e 1890, p.202) ${ }^{47}$. Na conta que envia a 27 de novembro ao Visconde de Balsemão (provavelmente com informações que recebera de Coimbra), o reitor refere que o conflito não teria sido tão grave como é referido, mas que teria sido iniciado pelos estudantes (O INSTITUTO, 1889 e 1890, p.202; RODRIGUES, 1990. p.174). A situação não se resolveu de imediato e acabou por se arrastar o que levou o reitor a apontar uma possível conclusão: que o regente decidisse sobre as penas a aplicar embora apontasse possíveis castigos. Pretendia assim dividir os criminosos segundo a sua participação nos desacatos e estabelecer penas adequadas: os mais implicados deveriam ser riscados da Universidade e degredados para a Índia ${ }^{48}$. Mas o degredo deveria ser usado para assustar os envolvidos, D. Francisco de Lemos propõe que esta pena lhes seja perdoada, mas só quando estivessem prestes a embarcar (O INSTITUTO, 1889 e 1890, p.203) - os restantes deviam apenas ser expulsos. Os comportamentos indignos não terminaram por aqui: em 1803 o vice-reitor refere a criação de um grupo composto por estudantes dos quais doze já haviam sido presos (O INSTITUTO, 1889 e 1890, p.564; RODRIGUES, 1990. p.175). O lente entende também que se deveria procurar atuar com alguma celeridade para que este comportamento não fosse visto como exemplar e, para além dos detidos, propõe que os restantes sejam incorporados no exército - chegando mesmo a comunicar com as autoridades militares para o efeito (O INSTITUTO, 1889 e 1890, p.654) ${ }^{49}$. O caso só ficou resolvido por volta de Outono do mesmo ano, onde se revelou que o grupo teria uma considerável dimensão: entre 50 e 60 estudantes, usufruiria de uma sede onde se reuniam e partiam para as suas rusgas violentas e tinham também emissários e sinais próprios ${ }^{50}$. Quanto aos líderes, que depressa foram todos presos, não seriam apenas 12 mas sim 18, e a decisão tomada pelo vice-reitor acaba por ter os resultados pretendidos - para além de terminar com o grupo, levou ao encerramento de alguns negócios que incentivavam estes comportamentos $^{51}$.

Mas estes momentos de clara indisciplina e nefastas consequências para a imagem da Universidade, levaram o reitor a procurar tomar medidas e aquilo a que Teófilo Braga já apelidou de regime inquisitorial (BRAGA, 1989b, p.256) tem de ser entendido como uma forma de proporcionar àUniversidade um maior poder de atuação e um aumento de poderes da sua posição: caminho que tanto o reitor como o vice-reitor já há muito vinham a percorrer como tem ficado claro nesta exposição. Isto mesmo levou o bispo a tirar o melhor partido possível das adversidades. Em pedido ao Regente, propunha que se atuasse em dois sentidos: em relação aos alunos da Universidade e, paralelamente, em relação à própria cidade. Quanto ao primeiro aspeto, pedia que, enquanto reitor, lhe fosse delegado o poder de fiscalizar livreiros, visto que estes seriam os distribuidores de uma falsa doutrinaque estava a chegar àUniversidade através de obras não controladas; e até para inspecionar as casas dos estudantes na procura dos maus livros ${ }^{52}$. Pretendia também passar a exigir a todos os alunos que se matriculassem na Universidadea realização prévia de um exame onde se procurasse saber se conheciam os princípios da religião. Mas as medidas não ficam por aqui, e solicitava também vigiar o comportamento dos estudantes em lugares de culto e 
inspecionar a própria imagem dos estudantes, obrigando-os a usar o traje típico. E mais uma vez, não se esquece de relembrar o degredo como castigo (O INSTITUTO, 1889 e 1890, p.628). Quanto à cidade o mesmo referia que se deveriam fazer algumas alterações: maior controlo, senão encerramento dos estabelecimentos de diversão e uma maior atenção às mulheres públicas - que deveriam ser expulsas ou então recolhidas e reeducadas, como acontecia em Lisboa (O INSTITUTO, 1889 e 1890, p.627). Mas as questões disciplinares não ficaram por aqui e em 1801 foi reportado o ataque de um aluno, João Pereira Batista, ao professor de Grego, Félix José Marques ${ }^{53}$. Após a reprovação no exame, devido à sua fraca prestação, o estudante insulta e ataca o docente com uma faca: e apesar de não o ter ferido, o vice-reitor age de imediato e ordena a prisão do aluno e mantém o mesmo no cárcere até ordens do reitor (O INSTITUTO, 1888 e 1889, p.797; PROENÇA, 1955, p.110 e 111). E ainda no mesmo ano, Monteiro da Rocha volta a referir o assunto apelando para a libertação do estudante, que até já teria feito as pazes com o lente de grego, e propondo que este reprovasse o respetivo ano letivo (O INSTITUTO, 1889 e 1890, p.57).

Quanto às falhas dos funcionários também foi possível recolher uma referência que nos apresenta informações muito insuficientes: um claro episódio de corrupção e indisciplina, envolvendo furtos de géneros que se adquiriam para o hospital, feitos pelos que tinham o encargo de os comprar, em conivência com um professor médico, José Pinto, que já encontrámos atrás - o despenseiro até já tinha fugido para Lisboa (1803) (O INSTITUTO, 1889 e 1890, p.562). Mas quanto a este caso só foi possível encontrar as instruções do vice-reitor que propôs a nomeação de indivíduos idóneos para os lugares.

\section{5. Desenvolvimento científico}

Na questão do Desenvolvimento Cientifico - 5 referências em 1801, 1802 e 1803 foi possível encontrar algumas informações sobre três importantes assuntos: as viagens do lente de matemática Manuel Pedro de Melo (a mais referida na fonte) e de alguns lentes de Medicina e a criação dos cosmógrafos. Estas viagens têm que ser entendidas como uma necessidade, compreendida pelos dirigentes universitários, em procurar trazer o conhecimento científico mais atualizado para a realidade nacional. A confiança e a esperança depositada neste empreendimento parece ter sido alta por parte do vice-reitor: isso mesmo fica visível na vontade de reatualizar as várias áreas do saber oferecidas pela Universidade e na realização dos Apontamentos sobre a viagem litteraria do doutor Manuel Pedro de Mello por si elaborados (O INSTITUTO, 1889 e 1890, p.56). Aqui são estabelecidos os passos a dar e os objetivos a perseguir ${ }^{54}$ : inteirar-se da evolução dos estudos públicos dos lugares onde passasse, das pessoas mais capazes, dos instrumentos mais avançados ${ }^{55}$, e teria também que estabelecer relações institucionais com organismos homónimos como seria o caso dos Gabinetes de História Natural e do Observatório. O objetivo de tal ligação seria o de promover a entrada dos avanços internacionais em solo nacional e de criar assim um intercâmbio de produtos coloniais de diversos países $(\mathrm{O}$ INSTITUTO, 1889 e 1890, p.269). Por esta altura o Observatório da Universidade ainda estaria a carecer de algumas alterações - a elaboração do regulamento - e o lente de Matemática entendeu que nesta área muito se poderia aprender com outros semelhantes em termos técnicos e humanos. E quanto às áreas que iriam receber uma maior atenção foram: a Astronomia e a Hidráulica (foi por esta altura que uma cadeira com semelhante nomenclatura foi criada pelo reitor). Quanto à última as instruções também são claras: analisar todas as obras nesta matéria como portos, canais, diques e tirar as suas conclusões com o objetivo claro de aplicar as observações à realidade nacional ${ }^{56}$. Relativamente à viagem do lente Manuel Pedro, a informação inicial aponta para o primeiro resultado: em 
1802, como parte das suas tarefas, aponta um nome para procurador da Universidade em Paris, Luís Rafael Soyé - mas este não foi bem-recebido pelo vice-reitor que o achou de caráter perigoso e acaba ele mesmo por propor dois indivíduos ${ }^{57}$. Quanto às viagens médicas as informações aparecem em 1803, e o que fica logo visível é a insatisfação do lente. A viagem do docente de medicina Heliodoro Jacinto de Araújo de Carneiro foi para José Monteiro da Rocha um desperdício ${ }^{58}$ : entende que teria sido mais benéfico promover a viagem dos irmãos Navarro, Vicente e Sebastião, a Paris - a preocupação do lente seria a de enviar apenas os mais competentes (PROENÇA, 1955, p.560). O que foi acima de tudo uma preocupação legítima, que visava a concretização dos objetivos propostos e o principal interesse da instituição ${ }^{59}$. O mesmo se passou com a indicação de José Lourenço Martins, demonstrador de Botânica - os seus conhecimentos numa área a desenvolver seriam essenciais para o progresso da mesma após a viagem ${ }^{60}$.

Quanto à Lei dos Cosmógrafos, que pretendia incentivar os alunos de Matemática, foi da autoria do prelado e pretendia estabelecer um controlo sobre as obras públicas, a elaboração de cartas topográficas das diversas comarcas e a realização de observações astronómicas $^{61}$. A primeira informação nesta matéria diz respeito às nomeações dos cosmógrafos: Monteiro da Rocha propôs que se fizesse por concurso dos opositores ou por consultas da Congregação e numa terceira hipótese pelo Conselho da Fazenda. Para o vicereitor as duas primeiras vias seriam as melhores - dariam um maior controlo da seleção. E, ao apresentar os nomes dos que haviam concorrido para o lugar, aponta as linhas essenciais do regimento para estes concursos. Já as condições de operacionalidade (ajudantes, escrivães, instrumentos) foram outra das preocupações de Monteiro da Rocha: tudo deveria ficar sob a alçada da Universidade (O INSTITUTO, 1889 e 1890, p.478 e 479). Mas apesar do empenho e boa vontade na perspetivação destas expedições científicas, os viajantes seguiram destinos opostos, o que levou ao fim dos projetos ${ }^{62}$.

\section{A porção administrativa}

\subsection{Representação institucional}

Neste ponto irei tratar o que entendi designar por representação institucional e que diz respeito às várias deputações enviadas em nome da Universidade à presença do Regente, o que acontecia quando alguma situação em especial assim o pedia. Este assunto foi referenciado 13 vezes e teve uma presença constante durante o período analisado, ficando patente a relevância desta questão na vida da Universidade quer no que diz respeito à forma da escolha dos membros para as deputações quer pela importância das mesmas para a instituição.

Um primeiro tema a ter em conta é uma consideração genérica sobre a composição dessas deputações que merece de Monteiro da Rocha críticas mordazes e questiona a rotatividade das mesmas (O INSTITUTO, 1888 e 1889, p.452). A preocupação estaria no facto de que os enviados deveriam ser escolhidos segundo a sua própria importância, dentro da Universidade, e a relevância da ocasião e propõe ao reitor a implementação da ideia para que não se dessem mais desvios: esta representação institucional exibia a própria imagem da Universidade e o respeito desta pelas solenidades em que se fazia mostrar (O INSTITUTO, 1888 e 1889, p.512). Mas a questão prolongou-se e isso mesmo foi visível nas constantes queixas do lente. Em 1801 o problema ainda parece manter-se e a resposta do reitor ainda não teria chegado: tudo aponta para que José Monteiro da Rocha tenha aplicado a sua solução e que não teve nenhuma oposição no conselho em que a apresentou (O INSTITUTO, 1888 e 1889, p.794). Com isto não conseguiu apenas uma forma mais 
equilibrada de representar a Universidade em ocasiões importantes, ganhou também o poder de propor pessoalmente os lentes para as deputações ${ }^{63}$. Mas nota-se que o próprio pretende que o reitor também escolha os membros das futuras deputações, o que pode ser justificado como uma forma de apoio - se o prelado nomeasse, pouca resistência poderia existir, o que ajudaria e muito na implementação da ideia do lente. O outro problema prendia-se com o delegado representativo: uma espécie de procurador da Universidade junto da autoridade eclesiástica - a sua função não é clara. Monteiro da Rocha relembra o exemplo de João Crisóstomo - o qual não deixou boas lembranças do seu desempenho - e propõe uma menor interferência do delegado (que propõe, mas não identifica) nos negócios da Universidade(O INSTITUTO, 1889 e 1890, p.624).

\subsection{A complexidade da direção}

$\mathrm{Na}$ gestão administrativa, tema que teve breves referências, foi possível reunir vários assuntos: Cerimonial, Funcionários, Jardim Botânico, Administração e Obras. Quanto ao primeiro, volta a ser visível a ação do vice-reitor enquanto que por parte do reitor só foi possível ver uma única instrução. Várias foram as cerimónias que receberam a atenção do lente e que por si foram organizadas: as festas em honra do nascimento das infantas em 1800 e de novo em 1801 onde também se celebrou o aniversário do Regente e do nascimento do infante em 1802 (O INSTITUTO, 1888 e 1889, p.509 e 793; O INSTITUTO, 1889 e 1890, p.339). Para o aniversário do regente, encarregou o lente Nicolau Soares de realizar a recitação (O INSTITUTO, 1888 e 1889, p.662) e para a cerimónia de encerramento do ano letivo de 1801, escolhe Manuel Pacheco como orador $(\mathrm{O}$ INSTITUTO, 1888 e 1889, p.794). Por parte do reitor o que até nos chegou foi apenas um aviso para que todos não descurassem o uso das devidas insígnias na festividade em honra da infanta em 1801 - pedido que foi depressa foi atendido pelo lente (O INSTITUTO, 1888 e 1889, p.736).

Relativamente aos funcionários, podemos desde logo concluir que a escolha destes esteve sempre nas mãos de José Monteiro da Rocha: a proximidade com a Universidade levou a que estivesse em melhores condições de propor os candidatos. O principal problema que se fez sentir logo em 1800 e se arrastou pelos restantes anos foi mesmo o grande número de vagas embora não fosse possível encontrar o motivo (O INSTITUTO, 1888 e 1889, p.589) - a instabilidade internacional e nacional e o medo de uma possível invasão poderiam ter sido a causa. Perante este problema o lente de Matemática trata de promover gente capaz para as ditas vacaturas: o primeiro lugar ocupado foi o de contínuo dos gerais - embora não fosse possível encontrar o nome do eleito ficámos a saber que seria irmão do antigo ocupante do mesmo posto (O INSTITUTO, 1888 e 1889, p.375); em 1802 foi a vez do praticante do guarda (José Joaquim de Miranda), do porteiro do Observatório (António de Almeida e Silva) - ambos filhos de outros funcionários da Universidade e ambos já tinham dado sinais de competência ${ }^{64}$ - e do intendente do hospital (João António) - deixando o aviso de que este devia ser aumentado - (O INSTITUTO, 1889 e 1890, p.275). O que podemos ver nestas contratações é que o lente sempre optou por indivíduos de origem conhecida, muito provavelmente porque assim conseguiria atestar a sua confiança e capacidades. Mas o vice-reitor não tinha apenas a tarefa de contratar, também foi possível ver um caso onde não hesitou em despedir devido à indisciplina e acusações de fraude (no hospital que atrás já referimos): o dispensado foi o despenseiro (O INSTITUTO, 1889 e 1890, p.560).

As preocupações com o Jardim Botânico também foram evidentes e foi possível averiguar que as preocupações do lente se prendiam com a extensão do plano de 
intervenção - demasiado despropositado e carecia de correção - e a despesa que então se fazia sentir com o jardim (O INSTITUTO, 1888 e 1889, p.562 e 563). Mas a resposta do reitor a estes problemas foi breve: refere que o terreno dos Marianos já teria sido adquirido e quanto aos excessos não foi possível encontrar mais informações (O INSTITUTO, 1889 e $1890, \mathrm{p} .801)^{65}$.

Como se disse um dos assuntos que se incluiu nesta parte foi a Administração. A primeira informação diz respeito a uma doação do cónego Pacheco que por sua morte tinha deixado 60 mil cruzados e destes a terça parte seria para o hospital: o problema estaria na vontade de um seu sobrinho em anular o testamento - embora a quantia em questão já estava nos cofres da Universidade (O INSTITUTO, 1888 e 1889, p.305). Quanto a outra referência (única) indica-nos uma tentativa de desvio de uns dízimos pertencentes à Universidade e nesse sentido o lente pede a intervenção do bispo (O INSTITUTO, 1889 e 1890, p.131). Um outro tema é relativo ao assunto intitulado de Obras e a única informação recolhida indica-nos que a Via Latina estaria em obras e que deveria estar terminada em novembro de 1801 (O INSTITUTO, 1889 e 1890, p.197).

\section{Conclusão}

Procurando agora responder a questão levantada no título deste artigo, a conclusão que podemos retirar é que, claramente, a ação dos dirigentes universitários foi mutuamente complementada. Atuando em zonas diferentes - um em Coimbra e o outro em Lisboa conseguiram trabalhar em prol do melhoramento da Universidade.

E se D. Francisco de Lemos teve uma ação preponderante na capital junto do Regente, onde intervinha na última fase dos processos. Isto não quer dizer que apenas participasse nessa fase: as decisões, como vimos, eram na sua maioria tomadas em conjunto e só depois iriam para a necessária aprovação de Lisboa.

Desta forma, a expressão ação conjunta, é aqui usada como uma forma de complementaridade de dois atores que chefiavam a Universidade de Coimbra num dos seus momentos mais conturbados.

Como medidas mais significativastemos que realçarprincipalmente a Questão Medica, que foi uma das mais interessantes iniciativas, apesar do insucesso, a criação de varias cadeiras novas para alguns cursos da Universidade e as varias decisões e passos dados no ensino médio.

\section{Referências}

ALVES, Carlos F. T. D. Francisco de Lemos- Perfil de um Reitor Reformador. Dissertação de Mestrado em História apresentada ao Departamento História, Estudos Europeus, Arqueologia e Artes da Faculdade de Letras da Universidade de Coimbra. Coimbra: Faculdade de Letras da Universidade de Coimbra, 2016.

BRAGA, Teófilo. Historia da Universidade de Coimbra. Nas suas relações com a Instrucção Publica Portugueza. III. Lisboa: Por Ordem e na Typographia da Academia Real das Sciencias, 1989a.

BRAGA, Teófilo. Historia da Universidade de Coimbra. Nas suas relações com a Instrucção Publica Portugueza. IV. Lisboa: Por Ordem e na Typographia da Academia Real das Sciencias, 1989b. 
CARVALHO, Joaquim Martins de. D. Francisco de Lemos e a Lanterna Magica. $O$ Conimbricense, Coimbra, $\mathrm{n}^{\circ}$ 4623, ano de 1891.

CARVALHO, Rómulo de. História do ensino em Portugal. Desde a fundação da nacionalidade até ao fim do Regime de Salazar-Caetano. $2^{\mathrm{a}}$ Edição. Lisboa: Fundação Calouste Gulbenkian, 1986.

LEMOS, Maximiano. História da medicina em Portugal. Doutrinas e instituições. v. 2. Lisboa: Publicações Dom Quixote/Ordem dos Médicos: 1991.

O Instituto Revista Scientifica e Litteraria. Cartas do Dr. José Monteiro da Rocha a D. Francisco de Lemos de Faria Pereira Coutinho, Coimbra, v. 36, Segunda serie, n 5, nº, $\mathrm{n}^{\circ} 7, \mathrm{n}^{\circ} 8, \mathrm{n}^{\circ} 9, \mathrm{n}^{\circ} 10, \mathrm{n}^{\circ} 11$ e $\mathrm{n}^{\circ} 12,1888$ e 1889.

O Instituto Revista Scientifica e Litteraria. Cartas do Dr. José Monteiro da Rocha a D. Francisco de Lemos de Faria Pereira Coutinho, Coimbra, v. 37, Segunda serie, $\mathrm{n}^{\circ} 1, \mathrm{n}^{\circ} 2$, $\mathrm{n}^{\mathrm{o}} 3, \mathrm{n}^{\circ} 4, \mathrm{n}^{\circ} 5, \mathrm{n}^{\circ} 7, \mathrm{n}^{\circ} 8, \mathrm{n}^{\circ} 9, \mathrm{n}^{\circ} 10, \mathrm{n}^{\circ} 11$ e $\mathrm{n}^{\circ} 12,1889$ e 1890.

PITA, João Rui. Farmácia, medicina e saúde pública em Portugal (1772-1836). Coimbra: Minerva, 1996.

PROENÇA, Genoveva Marques. D. Francisco de Lemos de Faria Pereira Coutinho. Reitor da Universidade de Coimbra. Coimbra: Dissertação para a licenciatura em Ciências Histórico e Filosóficas, 1955.

RODRIGUES, Manuel Augusto. A Universidade de Coimbra e os seus Reitores. Para uma história da Instituição. Coimbra: Publicação do Arquivo da Universidade de Coimbra, 1990.

TEIXEIRA, António José. Apontamentos para a biografia de D. Francisco de Lemos de Faria Pereira Coutinho. O Instituto Revista Scientifica e Litteraria, Coimbra, v. 37, Segunda serie, n 1, 1889.

\footnotetext{
${ }^{1}$ Programa Interuniversitário de Doutoramento em História: mudança e continuidade num mundo Global (PIUDHIST-ICS-UL); Centro de História da Sociedade e da Cultura da Universidade de Coimbra (CHSCUC). Doutorando do Programa Interuniversitário de Doutoramento em História: mudança e continuidade num mundo global (PIUDHist), no Instituto de Ciências Sociais da Universidade de Lisboa (ICS-UL), Bolseiro de Doutoramento da Fundação para a Ciência e a Tecnologia (FCT - PD/BD/128127/2016) e, colaborador no Centro de História da Sociedade e da Cultura da Universidade de Coimbra (CHSC-UC). Correio eletrónico: cftalves@ outlook.pt.

${ }^{2} \mathrm{O}$ alvará de janeiro de 1791 da à Universidade o controlo dos estudos menores da comarca de Coimbra.

${ }^{3}$ Também não podemos esquecer que o reitor já teria uma idade avançada e um estado de saúde frágil.

${ }^{4}$ A mesma fonte foi parcialmente tratada por Teófilo Braga e Genoveva Proença. Quanto ao autor das ditas transcrições não foi possível definir, mas Genoveva Proença indica que teria sido António José Teixeira.

${ }^{5}$ As vias usadas designavam-se de ordinário e extraordinário (O INSTITUTO, 1888 e 1889, p. 660 e 661).
} 
${ }^{6}$ Rómulo de Carvalho afirmou que esta medida vinha também complementar a de 1791. Quanto a Junta teria um presidente, seis deputados e um secretário e todos deveriam de ser escolhidos de entre os docentes universitários. Formando assim uma clara dependência deste novo corpo à instituição universitária (CARVALHO, 1986, p.497). Para saber mais sobre o papel do Presidente (PROENÇA, 1955, p.87 e 88).

${ }^{7} \mathrm{O}$ provimento dos professores e mestres era feito por concurso; posteriormente, seriam examinados por um júri e só depois aprovados (CARVALHO, 1986, p.497). Mas apesar de esta ser a norma, alguns professores foram apresentados pelos altos dirigentes da Junta.

${ }^{8}$ Acabou por gozar do privilégio de eleger, por ordem do reitor, o Secretário. Mas acabou por se demitir do seu cargo devido ao facto de não concordar com a subordinação da Junta à Universidade e pela interferência na nomeação de alguns deputados (BRAGA, 1989b, p.244).

9 Teófilo Braga entende esta nomeação como uma forma de fortificar o elemento pombalista: remetendo para uma ideia em que de novo se tentava o que não se conseguiu em 1772 (BRAGA, 1989b, p.247).

${ }^{10} \mathrm{Um}$ dos candidatos foi António Soares Barbosa que, segundo o vice-reitor, não deveria ser nomeado porque teria apresentado alguns entraves aos poderes do presidente da Junta(BRAGA, 1989b, p.245).

${ }^{11}$ No caso do último, teve a oportunidade de melhorar as suas competências para depois entrar em funções.

${ }^{12}$ Um ano depois ainda nada se tinha decidido e o lente tem que voltar ao mesmo assunto.

${ }^{13}$ Para acabar com este cenário propõe uma fiscalização mais eficaz (O INSTITUTO, 1888 e 1889, p.308).

${ }^{14}$ A esta ideia atende positivamente o reitor que ainda em Lisboa consegue concretizar o pedido.

${ }^{15}$ Os valores não foram fixos e em 1801 são aumentados (O INSTITUTO, 1888 e 1889, p.733).

${ }^{16}$ José Monteiro da Rocha descontente com a forma de recolha do imposto procura arranjar uma solução que deveria passar pelo reitor para assim evitar mais constrangimentos.

17 Outra tarefa que fez parte das funções da Junta foi a publicação de editais, que deveriam servir para informar sobre a sua ação e funções (sendo enviados para todas as zonas do reino) - mas esta tarefa só se realizou por etapas durante todo o ano de 1800. Um procedimento usual, foi o de algumas vezes os editais terem sido enviados para o reitor, para aprovação, e só depois reenviados para os seus destinos.

${ }^{18}$ O mesmo já foi evidenciado por outros autores (BRAGA, 1989b, p.244; PROENÇA, 1955, p.89).

19 Esta tensão mantém-se e em 1809 é criado em Lisboa um sistema de inspeção escolar que deveria fiscalizar a atividade dos docentes do secundário: seria uma forma clara de pôr em causa a autonomia da Universidade na questão dos estudos menores - só alterada em 1812 (CARVALHO, 1986, p.498).

${ }^{20}$ Parte da tarefa já teria sido realizada pelo lente ainda em 1800 - tratava-se agora de um acrescento.

$21 \mathrm{Na}$ melhor das hipóteses, até à promulgação da lei, que se avisassem os respetivos responsáveis no ultramar que a Junta passaria a tratar das matérias de ensino, mas que este aviso fosse da parte do Regente e com esta legitimidade não se pudesse contestar (O INSTITUTO, 1888 e 1889, p.373).

22 Esta cedência dificilmente se concretizaria: o Colégio dos Nobres estava a cargo da Secretaria de Estado dos Negócios do Reino (CARVALHO, 1986, p.497).

${ }^{23}$ E estes, existentes na Universidade, beneficiariam desta medida (O INSTITUTO, 1889 e 1890, p.201).

24 Á exceção de uma referência, todas as outras apontam claramente no sentido de procurar o caminho pela paz (O INSTITUTO, 1888 e 1889, p.511; BRAGA, 1989b, p.248 e 249). 
${ }^{25}$ A Guerra das Laranjas e o Tratado de Badajoz não o permitiram (O INSTITUTO,1889 e 1890, p.132).

${ }^{26}$ O número de regimentos só diminui gradualmente em 1801 (O INSTITUTO, 1889 e 1890, p.132 e 199).

${ }^{27}$ Monteiro da Rocha não se sentia devidamente recompensado (O INSTITUTO, 1988, 1889,1890, p.513).

${ }^{28} \mathrm{O}$ grande receio seria o de passar a ideia de que o cargo lhe fora concedido devido ao Reitor, embora, tenha sido provavelmente isso mesmo que deveria ter acontecido (O INSTITUTO,1889 e 1890, p.339).

${ }^{29}$ Esta foi a única referência á Junta dos Três Estados (O INSTITUTO, 1889 e 1890, p.714).

${ }^{30}$ A vontade que o prelado demonstrou em melhorar a condição da medicina em Portugal já vem do seu primeiro reitorado onde teria preparado um plano para os Tribunais de Saúde (PROENÇA, 1955, p.29 e 30 e 106 e 107). E segundo Teófilo Braga, pretendia também alcançar alguma preponderância sobre a Junta do Protomedicato de Lisboa (BRAGA, 1989b, p.249).

${ }^{31}$ Diretor Perpétuo, decano da Faculdade, inspetor e administrador do hospital e deputado da diretoria.

32 É necessário salientar que o Presidente do Conselho não seria o reitor mas sim alguém com formação em Medicina - o reitor seria uma autoridade distinta e superior (O INSTITUTO, 1888 e 1889, p.795 e 796).

${ }^{33}$ Esta criação acabou por se tornar Real Junta em 1799 (PITA, 1996. p. 490).

${ }^{34}$ A mesma ideia já foi evidenciada por outra autora (PROENÇA, 1955, p.107.

${ }^{35} \mathrm{O}$ esquema utilizado era o seguinte: o lente indicava e o Reitor tratava de oficializar junto do Regente. Este pedido demorou a ser correspondido e em 1816 o lente volta a referir esta necessidade.

36 A jubilação deste lente foi complicada por razões que se desconhecem: em 1807 ainda não tinha acontecido e José Monteiro da Rocha tem que repetir o pedido (O INSTITUTO, 1889 e 1890, p.802).

${ }^{37}$ Mas esta prática, apesar de a fonte não nos fornecer tal informação, também foi usada pelo reitor, que no sentido de melhorar a qualidade da cadeira de música, opta por jubilar Manuel José Ferreira por este não ter o melhor desempenho. Promovendo um já seu conhecido, José Maurício (BRAGA, 1989b, p.258 á 261).

${ }^{38}$ Quanto à jubilação deste só teria acontecido após 1802 (O INSTITUTO, 1889 e 1890, p.475.)

${ }^{39} \mathrm{O}$ problema foi evidente com a fuga de alguns lentes durante as invasões (RODRIGUES, 1990. p. 180).

${ }^{40}$ Genoveva Marques indica que o mesmo se passou com a inclusão da cadeira de Metalurgia (PROENÇA, 1955, p.102). Que como já referimos, o problema deveu-se ao respetivo professor.

${ }^{41}$ O Alvará de 16 de janeiro oficializa as alterações (BRAGA, 1989b, p.275; RODRIGUES, 1990. p. 176).

42 Teófilo Braga chamou a atenção para a mesma ação (BRAGA, 1989b, p.247).

${ }^{43} \mathrm{O}$ atraso do envio das cartas protelou os exames de Leis. Monteiro da Rocha propôs algumas hipóteses de solução (O INSTITUTO, 1888 e 1889, p.511).

${ }^{44} \mathrm{O}$ lente foi bem explícito neste ponto (O INSTITUTO, 1889 e 1890, p.55).

45 O lente temia alguma ação contra a Universidade, mas não deixou claro de quem é que poderia vir essa ação e o que seria (O INSTITUTO, 1889 e 1890, p.55).

${ }^{46}$ Esta obra já tinha sido usada no reitorado anterior e também aí já tinha sido readaptada. 


\footnotetext{
${ }^{47}$ Trata-se do relatório enviado pelo reitor ao Secretário de Estado dos Negócios do Reino.

48 João da Costa Regueira, José Ascânio e Francisco Xavier Monteiro (O INSTITUTO, 1889 e 1890, p.203).

${ }^{49}$ Esta medida já teria um precedente: em 1801 foi expedido um aviso régio onde se determinava que caberia ao reitor prender e enviar, quem tivesse insucesso escolar, ao Intendente Geral da Policia para serem alistados no exército e cumprirem a carreira militar (RODRIGUES, 1990. p.174).
}

50 Nesta é também possível ver que estas rusgas de violência, precedidas por consumo de álcool e por convívio com meretrizes, originavam vários crimes e distúrbios (O INSTITUTO, 1889 e 1890, p.622; PROENÇA, 1955, p.111; RODRIGUES, 1990. p.175).

${ }^{51} \mathrm{O}$ lucro destes foi severamente atingido e levou a falências (O INSTITUTO, 1889 e 1890, p.622).

${ }^{52}$ Os livreiros da cidade do Mondego deveriam também ser proibidos de vender livros que tivessem chegado de outras cidades sem primeiro comunicarem as aquisições (O INSTITUTO, 1889 e 1890, p.626).

${ }^{53}$ Mas este comportamento violento, que na fonte analisada só foi possível verificar uma vez, foi bem mais presente durante este período. Em 1803 um outro aluno desrespeita os lentes e acabou por ver o seu doutoramento anulado e foi preso (RODRIGUES, 1990. p.75).

${ }^{54}$ Genoveva Marques refere que seria ao reitor que caberia a organização do plano das viagens, da escolha das pessoas e dos valores envolvidos (PROENÇA, 1955, p.96). Mas depois de analisada a fonte ficou-nos outra impressão: parece ter havido uma ação bem mais evidente do lente de Matemática quanto aos pontos referidos enquanto a ação do prelado se viu mais numa fase final, a aprovação - embora os passos do exjesuíta estivessem em consonância e constante comunicação com o reitor.

55 Até esta altura, os instrumentos para as várias disciplinas vinham de Londres. Nesse sentido Manuel Pedro tinha também a missão, já que o representante da Universidade nessa capital tinha falecido, de procurar em Paris quem tratasse de construir os ditos instrumentos. Este, que passaria então a ser o procurador da Universidade em solo francês, teria como demais tarefas remeter os jornais literários de maior relevo, livros raros e manuscritos (O INSTITUTO, 1889 e 1890, p.268 e 269).

${ }^{56} \mathrm{O}$ sucesso daquilo que podemos denominar de obras públicas estaria na mente do vice-reitor que pretendia trazer melhoramentos para as construções nacionais (O INSTITUTO, 1889 e 1890, p.270).

${ }^{57}$ Não foi possível encontrar a escolha do reitor, ficou apenas o aviso de Monteiro da Rocha de que o prelado deveria agir rapidamente para que Luís Rafael Soyé não começasse a procurar apoios para o cargo (O INSTITUTO, 1889 e 1890, p.275).

58 Como a Junta da Fazenda criou vários obstáculos ao professor de Medicina, este acabou por conseguir financiamento no Erário - mas ficou obrigado a dirigir-se à Faculdade para conhecer as instruções da sua viagem. Esta acabou por pedir que o seu destino fossem alguns países estrangeiros, mas o vice-reitor acaba por conseguir enviá-lo para as terras do reino que estariam a sofrer de qualquer maleita - só mais tarde o reitor permitiu a ida ao estrangeiro. (PROENÇA, 1955, p.98, 99 e 100).

${ }^{59}$ Quanto as áreas em evidência na viagem dos irmãos foram não só a Medicina, mas também a Filosofia. E pretendia-se que: aprofundassem as suas competências em anatomia, operações, partos, química e tinham de tirar conclusões sobre as questões financeiras de tais processos. (PROENÇA, 1955, p.560). Os propostos foram aceites pelo reitor que tratou da autorização junto do Regente (PROENÇA, 1955, p.96).

${ }^{60} \mathrm{Na}$ mesma missiva é possível ver a ação do vice-reitor na escolha dos que deveriam fazer as viagens e nos orçamentos para as mesmas - o que vem apenas reforçar a ideia de que ao lente coube a maior parcela na planificação destas expedições (O INSTITUTO, 1889 e 1890, p.561). 
${ }^{61}$ Este vasto grupo de cosmógrafos seria liderado pelo lente que mais se distinguisse e cada comarca deveria albergar um cosmógrafo - com instrução em Matemática, teria os privilégios e o vencimento idênticos aos provedores (PROENÇA, 1955, p.102, 103 e 104). Os lugares de cosmógrafos deveriam ser preenchidos por estudantes da Universidade, abrindo-se uma porta para o futuro dos alunos de Matemática.

62 O Dr. Heliodoro não reportou as conclusões à Faculdade; o Dr. Vicente Navarro optou por uma carreira diplomática e Manuel Pedro apenas apresentou observações gerais (PROENÇA, 1955, p.96, 99 e 101).

${ }^{63}$ De que é exemplo José Bonifácio (O INSTITUTO, 1888 e 1889, p.795).

${ }^{64} \mathrm{O}$ primeiro era filho do guarda do Observatório; o segundo do contínuo da livraria (O INSTITUTO, 1889 e 1890, p.272).

${ }^{65}$ Um problema de relevo, não encontrado na fonte analisada, foi a desavença entre o lente de Matemática e o Dr. Félix de Avelar Brotero (BRAGA, 1989b, p.262 e 263).

Recebido: Abril/2016.

Aprovado: Março/2017. 